\title{
Penerapan Asuhan Keperawatan Jiwa Dengan Masalah Kecemasan Pada Penderita Hipertensi: Studi Kasus
}

\section{Basilius Ekadarman Putra Gulo}

\author{
basiliusep01@gmail.com
}

\section{BAB 1}

\section{PENDAHULUAN}

\subsection{Latar Belakang}

Hipertensi merupakan penyakit kardiovaskuler atau kategori penyakit yang tidak menular (PTM) yang telah menjadi endemik. Hipertensi adalah suatu keadaan dimana tekanan darah sistolik $\geq 140 \mathrm{mmHg}$ dan atau tekanan darah diastolik $\geq 90 \mathrm{mmHg}$ (JNC-VII, 2003). Hipertensi merupakan penyebab kematian nomor 3 setelah stroke dan tuberkulosis, yakni mencapai 6,7\% dari populasi kematian pada semua umur di Indonesia. Prevalensi hipertensi akan terus meningkat tajam, diprediksikan pada tahun 2025 nanti, sekitar 29\% orang dewasa di seluruh dunia menderita hipertensi. Hipertensi telah mengakibatkan kematian sekitar 8 juta orang setiap tahun, 1,5 juta kematian terjadi di Asia Tenggara, yang sepertiga populasinya menderita hipertensi (Kemenkes RI, 2016). Tanpa disadari penderita mengalami komplikasi pada organ-organ vital seperti jantung, otak ataupun ginjal. Gejala-gejala akibat hipertensi, seperti pusing, gangguan penglihatan, dan sakit kepala, sering kali terjadi pada saat hipertensi sudah lanjut disaat tekanan darah sudah mencapai angka tertentu yang bermakna (Triyanto, 2019).

Ansietas merupakan perasaan takut atau ketakutan yang tidak dapat dijelaskan dan merupakan respon stimulus internal dan eksternal yang memiliki tanda dan gejala perilaku, afektif, kognitif dan fisik. Ansietas merupakan suatu respons emosonal sebagai antisipasi terhadap bahaya. Respon individu terhadap ansietas mempunyai rentang antara adaptif sampai maladaptif. Respon adaftif identik dengan reaksi yang bersifat destruktif. Reaksi yang bersifat kontruktif menunjukkan sikap optimis dan berusaha 
memahami terhadap perubahan perubahan yang terjadi baik perubahan fisik maupun efektif (Pardede \& Marbun, 2019).

Di Indonesia prevalensi kecemasan belum diketahui secara pasti, namun diprdiksi sekitar 9-12\% populasi penduduk mengalami kecemasan. Hasil penelitian Apriansyah, Romadoni dan Andrianovita (2014) bahwa responden yang akan dilakukan tindakan operasi mengalami kecemasan kategori sedang dan berat berjumlah 23 responden (50\%) dari total 46 responden yang diteliti dan kecemasan ringan yang terjadi pada responden demngan keluhan nyeri berjumlah 10 responden $(21,7 \%)$ dari total 46 responden (Pardede et al., 2021)

Kota Medan Merupakan salah satu Kota Di Provinsi Sumatera Utara yang memiliki masalah dengan hipertensi. Berdasarkan data Indeks Pembangunan Kesehatan Masyarakat tahun 2016, prevalensi hipertensi Kota Medan adalah $26,27 \%$, data ini lebih tinggi dari prevalensi Sumatera Utara $(22,99 \%)$ dan prevalensi Indonesia (24,33\%). Kecamatan Medan Helvetia merupakan kecamatan dengan jumlah kasus tertinggi di kota Medan pada tahun 2017. Data kasus hipertensi pada dewasa muda di kecamatan medan Helvetia pada tahun 2014 adalah 544 orang dan jumlah penduduk usia 18-45 tahun adalah 108.626 orang (Dinkes Kota Medan, 2017).

Menurut data dari Riskesdas tahun 2017 menyatakan bahwa lansia yang mengalami kecemasan menyebabkan terjadinya peningkatan tekanan darah. Kecemasan adalah kekhawatiran yang tidak jelas dan menyebar yang berkaitan dengan perasaan tidak pasti dan tidak berdaya. Keadaan emosi ini tidak memiliki obyek yang spesifik. Gangguan kecemasan dan depresi di derita oleh 40 juta populasi orang dewasa di Amerika dan diprediksi 20\% dari populasi dunia menderita kecemasan (Kaplan \& Sadock, 2016).

Kecemasan adalah kekhawatiran yang tidak jelas dan menyebar, yang 
berkaitan dengan perasaan tidak pasti dan tidak berdaya. Keadaan emosi ini tidak memiliki objek yang spesifik. Kecemasan di alami secara subjektif dan dikomunikasikan secara interpersonal dapat menjadi suatu kekuatan motivasi untuk pertumbuhan dan perkembangan pada individu yang bersangkutan (Pardede \& Marbun, 2019). Stres akan meningkatkan resistensi pembuluh darah perifer dan curah jantung sehingga akan menstimulasi aktivitas syaraf simpatik. Adapun stres ini dapat berhubungan dengan pekerjaan, kelas sosial, ekonomi, dan karakteristik personal (Setyaningsih, 2015). Salah satu cara yang dapat ditempuh penderita hipertensi adalah dengan menghindari stres dan cemas yang berlebihan serta beristirahat dengan cukup. Sebagai manusia terkadang tidak dapat terus menerus menjaga agar kondisi yang dianjurkan dokter dapat dipertahankan, sebab stres dan cemas sewaktu-waktu dapat menyerang penderita hipertensi (Zahara, 2017). Hasil survey awal yang dilakukan di Jalan Bakti Luhur pada tanggal 1 Oktober 2021 kepada Ny. S yang menderita penyakit

\subsection{Tujuan}

\subsubsection{Tujuan Umum}

Berdasarkan latar belakang masalah tersebut maka dapat dirumuskan masalah sebagai berikut : Bagaimana Memberikan Asuhan Keperawatan Psikososial Pada Ny.S Dengan Masalah Kecemasan Di Jalan Bakti Luhur Medan Helvetia

\subsubsection{Tujuan Khusus}

1. Mahasiswa mampu mengetahui defenisi, tanda \& gejala, faktor penyebab, mekanisme koping, penatalaksanaan pada pasien dengan Hipertensi Pada Psikososial Kecemasan Di Jalan Bakti Luhur Medan Helvetia.

2. Mahasiswa mampu melakukan pengkajian pada pasien dengan Hipertensi Pada Psikososial Kecemasan Di Jalan Bakti Luhur Medan Helvetia. 
3. Mahasiswa mampu menegakkan diagnosa atau masalah keperawatan pada Ny.S dengan Hipertensi Pada Psikososial Kecemasan Di Jalan Bakti Luhur Medan Helvetia.

4. Mahasiswa mampu menetapkan intervensi keperawatan secara menyeluruh pada Ny.S dengan Hipertensi Pada Psikososial Kecemasan Di Jalan Bakti Luhur Medan Helvetia.

5. Mahasiswa mampu melakukan tindakan keperawatan yang nyata pada Ny.S dengan Hipertensi Pada Psikososial Kecemasan Di Jalan Bakti Luhur Medan Helvetia.

6. Mahasiswa mampu mengevaluasi sebagai tolak ukur guna menerapkan asuhan keperawatan pada Ny.S dengan Hipertensi Pada Psikososial Kecemasan Di Jalan Bakti Luhur Medan Helvetia.

7. Mahasiswa mampu mendokumentasikan asuhan keperawatan pada Ny.S dengan Hipertensi Pada Psikososial Kecemasan Di Jalan Bakti Luhur Medan Helvetia. 


\section{BAB 2}

\section{TINJAUAN TEORITIS}

\subsection{Konsep Hipertensi}

\subsubsection{Definisi}

Hipertensi atau tekanan darah tinggi adalah suatu keadaan dimana tekanan darah sistolik $\geq 140 \mathrm{mmHg}$ dan atau tekanan darah diastolic $\geq 90 \mathrm{mmHg}$ (WHO, 2020). Hipertensi atau tekanan darah tinggi adalah suatu peningkatan abnormal tekanan darah daalam pembuluh darah arteri secara terus menerus lebih dari suatu periode. Hipertensi merupakan penyebab kematian nomor 3 setelah stroke dan tuberkulosis, yakni mencapai 6,7\% dari populasi kematian pada semua umur di Indonesia. Hal ini terjadi bila arteriole-arteriole konstriksi. Kontriksi arteriole membuat darah sulit mengalir dan meningkatkan tekanan melawan dinding arteri. Hipertensi menambah beban kerja jantung dan arteri yang bila berlanjut dapat menimbulkan kerusakan jantung dan pembuluh darah (Setyawan \& Hasnah, 2020)

Berdasarkan penyebabnya hipertensi terbagi menjadi dua golongan :

a. Hipertensi primer atau hipertensi esensial

Hipertensi primer atau hipertensi esensial disebut juga hipertensi idiopatik karena tidak diketahui penyebabnya. Faktor yang memengaruhi yaitu :

1) Genetik

Individu yang mempunyai riwayat keluarga dengan hipertensi, beresiko tinggi untuk mendapatkan penyakit ini. Faktor genetik ini tidak dapat dikendalikan, jika memiliki riwayat keluarga yang memliki tekanan darah tinggi.

2) Jenis kelamin dan usia

Laki - laki berusia 35- 50 tahun dan wanita menopause beresiko tinggi untuk mengalami hipertensi. Jika usia bertambah maka tekanan darah meningkat faktor ini tidak dapat dikendalikan serta jenis kelamin laki-laki lebih tinggi dari pada perempuan 
3) Diet

Konsumsi diet tinggi garam secara langsung berhubungan dengan berkembangnya hipertensi. Faktor ini bisa dikendalikan oleh penderita dengan mengurangi konsumsinya, jika garam yang dikonsumsi berlebihan, ginjal yang bertugas untuk mengolah garam akan menahan cairan lebih banyak dari pada yang seharusnya didalam tubuh. Banyaknya cairan yang tertahan menyebabkan peningkatan pada volume darah. Beban ekstra yang dibawa oleh pembuluh darah inilah yang menyebabkan pembuluh darah bekerja ekstra yakni adanya peningkatan tekanan darah didalam dinding pembuluh darah dan menyebabkan tekanan darah meningkat.

4) Berat badan

Faktor ini dapat dikendalikan dimana bisa menjaga berat badan dalam keadaan normal atau ideal. Obesitas ( $>25 \%$ diatas BB ideal) dikaitkan dengan berkembangnya peningkatan tekanan darah atau hipertensi.

5) Gaya hidup

Faktor ini dapat dikendalikan dengan pasien hidup dengan pola hidup sehat dengan menghindari faktor pemicu hipertensi yaitu merokok, dengan merokok berkaitan dengan jumlah rokok yang dihisap dalam waktu sehari dan dapat menghabiskan berapa putung rokok dan lama merokok berpengaruh dengan tekanan darah pasien. Konsumsi alkohol yang sering, atau berlebihan dan terus menerus dapat meningkatkan tekanan darah pasien sebaiknya jika memiliki tekanan darah tinggi pasien diminta untuk menghindari alkohol agar tekanan darah pasien dalam batas stabil dan pelihara gaya hidup sehat penting agar terhindar dari komplikasi yang bisa terjadi.

b. Hipertensi sekunder

Hipertensi sekunder terjadi akibat penyebab yang jelas.salah satu contoh 
hipertensi sekunder adalah hipertensi vaskular rena, yang terjadiakibat stenosi arteri renalis. Kelainan ini dapat bersifat kongenital atau akibat aterosklerosis.stenosis arteri renalis menurunkan aliran darah ke ginjal sehingga terjadi pengaktifan baroreseptor ginjal, perangsangan pelepasn renin, dan pembentukan angiostenin II. Angiostenin II secara langsung meningkatkan tekanan darahdan secara tidak langsung meningkatkan sintesis andosteron dan reabsorbsi natrium. Apa bila dapat dilakukan perbaikan pada stenosis, atau apa bila ginjal yang terkena diangkat, tekanan darah akan kembali ke normal.

\subsubsection{Patofisiologi}

Tekanan arteri sistemik adalah hasil dari perkalian cardiac output (curah jantung) dengan total tahanan prifer. Cardiac output (curah jantung) diperoleh dari perkalian antara stroke volume dengan heart rate (denyut jantug). Pengaturan tahanan perifer dipertahankan oleh sistem saraf otonom dan sirkulasi hormon. Empat sistem kontrol yang berperan dalam mempertahankan tekanan darah antara lain sistem baroreseptor arteri, pengaturan volume cairan tubuh, sistem renin angiotensin dan autoregulasi vaskular. Mekanisme yang mengontrol konstriksi dan relaksasi pembuluh darah terletak di vasomotor, pada medula diotak. Pusat vasomotor ini bermula pada saraf simpatis, yang berlanjut ke bawah korda spinalis dan keluar dari kolumna medulla spinalis ganglia simpatis di toraks dan abdomen. Rangsangan pusat vasomotor dihantarkan dalam bentuk implus yang bergerak kebawah melalui sistem saraf simpatis ke ganglia simpatis. Titik neuron preganglion melepaskan asetilkolin, yang akan merangsang serabut saraf paska ganglion ke pembuluh darah, dimana dengan dilepaskannya noreepineprin mengakibatkan konstriksi pembuluh darah.

Berbagai faktor seperti kecemasan dan ketakutan dapat mempengaruhi respon pembuluh darah terhadap rangsangan vasokontriksi. Individu dengan hipertensi sangat sensitif terhadap norepinefrin, meskipun tidak diketahui dengan jelas mengapa hal tersebut bisa terjadi. Meski etiologi 
hipertensi masih belum jelas, banyak faktor diduga memegang peranan dalam genesis hiepertensi seperti yang sudah dijelaskan dan faktor psikis, system saraf, ginjal, jantung pembuluh darah, kortikosteroid, katekolamin, angiotensin, sodium, dan air.

Sistem saraf simpatis merangsang pembuluh darah sebagai respon rangsang emosi, kelenjar adrenal juga terangsang, mengakibatkan tambahan aktivitas vasokontriksi. Medulla adrenal mensekresi epinefrin, yang menyebabkan vasokontriksi. Korteks adrenal mensekresi kortisol dan steroid lainnya, yang dapat memperkuat respon vasokonstriktor pembuluh darah. Vasokonstriksi yang mengakibatkan penurunan aliran keginjal, menyebabkan pelepasan rennin. Rennin merangsang pembentukan angiotensin I yang kemudian diubah menjadi angiotensin II, suatu vasokonstriktor kuat, yang pada gilirannya merangsang sekresi aldosteron oleh korteks adrenal. Hormon ini menyebabkan retensi natrium dan air oleh tubulus ginjal, menyebabkan peningkatan volume intra vaskuler. Semua faktor ini cendrung mencetuskan keadaan hipertensi.

\subsubsection{Manifestasi Klinis}

Tanda dan gejala utama hipertensi adalah menyebutkan gejala umum yang ditimbulkan akibat hipertensi atau tekanan darah tinggi tidak sama pada setiap orang, bahkan terkadang timbul tanpa tanda gejala. Secara umum gejala yang dikeluhkan oleh penderita hipertensi sebagai berikut:

1. Sakit kepala

2. Rasa pegal dan tidak nyaman pada tengkuk

3. Perasaan berputar seperti tujuh keliling serasa ingin jatuh

4. Berdebar atau detak jantung terasa cepat

5. Telinga berdenging yang memerlukan penanganan segera 


\subsubsection{Komplikasi}

Tekanan darah tinggi bila tidak segera diobati atau ditanggulangi, dalam jangka panjang akan menyebabkan kerusakan ateri didalam tubuh sampai organ yang mendapat suplai darah dari arteri tersebut komplikasi yang dapat terjadi pada penderita hipertensi yaitu :

a. Stroke terjadi akibat hemoragi disebabkan oleh tekanan darah tinggi di otak dan akibat embolus yang terlepas dari pembuluh selain otak yang terpajan tekanan darah tinggi.

b. Infark miokard dapat terjadi bila arteri koroner yang arterosklerotik tidak dapat menyuplai cukup oksigen ke miokardium dan apabila membentuk 12 trombus yang bisa memperlambat aliran darah melewati pembuluh darah. Hipertensi kronis dan hipertrofi ventrikel, kebutuhan oksigen miokardium tidak dapat dipenuhi dan dapat terjadi iskemia jantung yang menyebabkan infark. Sedangkan hipertrofi ventrikel dapat menyebabkan perubahan waktu hantaran listrik melintasi ventrikel terjadilah disritmia, hipoksia jantung, dan peningkatan resiko pembentukan bekuan.

c. Gagal jantung dapat disebabkan oleh peningkatan darah tinggi. Penderita hipertensi, beban kerja jantung akan meningkat, otot jantung akan mengendor dan berkurang elastisitasnya, disebut dekompensasi. Akibatnya jantung tidak mampu lagi memompa, banyak cairan tertahan diparu yang dapat menyebabkan sesak nafas (eudema) kondisi ini disebut gagal jantung.

d. Ginjal tekanan darah tinggi bisa menyebabkan kerusakan ginjal. Merusak sistem penyaringan dalam ginjal akibat ginjal tidak dapat membuat zat-zat yang tidak dibutuhkan tubuh yang masuk melalui aliran darah dan terjadi penumpukan dalam tubuh.

\subsection{Konsep Kecemasan}

\subsubsection{Definisi}

Kecemasan (anxiety) merupakan perasaan takut yang tidak jelas penyebabnya dan tidak didukung oleh situasi yang ada. Kecemasan dapat 
dirasakan oleh setiap orang jika mengalami tekanan dan perasaan mendalam yang menyebabkan masalah psikiatrik dan dapat berkembang dalam jangka waktu lama. Kecemasan adalah kekhawatiran yang tidak jelas dan menyebar, yang berkaitan dengan perasaan tidak pasti dan tidak berdaya. Keadaan emosi ini tidak memiliki objek yang spesifik. Kecemasan di alami secara subjektif dan dikomunikasikan secara interpersonal dapat menjadi suatu kekuatan motivasi untuk pertumbuhan dan perkembangan pada individu yang bersangkutan (Marbun, Pardede, \& Perkasa, 2019)

Kecemasan adalah pengalaman subjektif dari ketegangan mental yang mengganggu sebagai reaksi umum dan ketidakmampuan untuk menghadapi masalah atau adanya rasa tidak aman. Perasaan tidak menyenangkan umumnya menimbulkan gejala fisiologis (seperti gemetar, berkeringat, detak jantung meningkat, dll) dan gejala psikologis seperti panik, tegang, bingung, tidak dapat berkonsentrasi, dll (Pardede, Simanjuntak, \& Manalu, 2020).

Kecemasan merupakan suatu keadaan perasaan gelisah, ketidaktentuan, ada rasa takut dari kenyataan atau persepsi ancaman sumber aktual yang tidak diketahui masalahnya (Pardede \& Simangunsong, 2020). Dapat pula kecemasan menjadi suatu beban berat yang menyebabkan individu tersebut hidupnya selalu di bawah bayang-bayang kecemasan yang terus berkepanjangan. Kecemasan berkaitan dengan strees. Oleh karena kecemasan timbul sebagai respon terhadap stress, baik stress fisiologi maupun psikologis. Artinya kecemasan terjadi ketika seseorang merasa terancam baik secara fisik maupun psikologis. Stres merupakan bagian yang tidak dapat terelakkan dalam hidup manusia. Meskkipun demikian, stress bukanlah merupakan sesuatu yang patologis (Pardede \& Marbun, 2019). 


\subsubsection{Etiologi}

Meski penyebab kecemasan belum sepenuhnya diketahui, namun gangguan keseimbangan neurotransmitter dalam otak dapat menimbulkan ansietas pada diri seseorang. Faktor genetik juga merupakan faktor yang dapat menimbulkan gangguan ini. Kecemasan terjadi ketika seseorang mengalami kesulitan menghadapi situasi, masalah dan tujuan hidup. Setiap individu menghadapi stres dengan cara yang berbeda-beda, seseorang dapat tumbuh dalam suatu situasi yang dapat menimbulkan stres berat pada orang lain. Adapun faktor-faktor yang mempengaruhi kecemasan (Setyaningsih, 2015) adalah :

2. Faktor Predisposisi

Stressor predisposisi adalah semua ketegangan dalam kehidupan yang dapat menyebabkan timbulnya kecemasan. Ketegangan dalam kehidupan tersebut dapat berupa :

a. Peristiwa Traumatik, yang dapat memicu terjadinya kecemasan berkaitan dengan krisis yang dialami individu baik krisis perkembangan atau situasional.

b. Konflik Emosional, yang dialami individu dan tidak terselesaikan dengan baik. Konflik antara id dan superego atau antara keinginan dan kenyataan dapat menimbulkan kecemasan pada individu.

c. Konsep diri terganggu akan menimbulkan ketidakmampuan individu berpikir secara realitas sehingga akan menimbulkan kecemasan.

d. Frustasi akan menimbulkan rasa ketidakberdayaan untuk mengambil keputusan yang berdampak terhadap ego.

e. Gangguan fisik akan menimbulkan kecemasan karena merupakan ancaman terhadap integritas fisik yang dapat mempengaruhi konsep diri individu.

f. Pola mekanisme koping keluarga atau pola keluarga menangani stress akan mempengaruhi individu dalam berespon terhadap konflik yang dialami karena pola mekanisme koping individu banyak dipelajari dalam keluarga. 
g. Riwayat gangguan kecemasan dalam keluarga akan mempengaruhi respons individu dalam berespons terhadap konflik dan mengatasi kecemasannya.

h. Medikasi yang dapat memicu terjadinya kecemasan adalah pengobatan yang mengandung benzodiazepin, karena benzodiazepine dapat menekan neurotransmiter gamma amino butyric acid (GABA) yang mengontrol aktivitas neuron di otak yang bertanggung jawab menghasilkan kecemasan.

\section{Faktor presipitasi}

Stresor presipitasi adalah semua ketegangan dalam kehidupan yang dapat mencetuskan timbulnya kecemasan (Setyaningsih, 2015). Stressor presipitasi kecemasan dikelompokkan menjadi dua bagian, yaitu

a. Ancaman terhadap integritas fisik. Ketegangan yang mengancam integritas fisik yang meliputi :

- Sumber Internal, meliputi kegagalan mekanisme fisiologis sistem imun, regulasi suhu tubuh, perubahan biologis normal (misalnya : hamil).

- Sumber Eksternal, meliputi paparan terhadap infeksi virus dan bakteri, polutan lingkungan, kecelakaan, kekurangan nutrisi, tidak adekuatnya tempat tinggal.

b. Ancaman terhadap harga diri meliputi sumber internal dan eksternal

- Sumber Internal : kesulitan dalam berhubungan interpersonal di rumah dan tempat kerja, penyesuaian terhadap peran baru. Berbagai ancaman terhadap integritas fisik juga dapat mengancam harga diri.

- Sumber Eksternal : kehilangan orang yang dicintai, perceraian, perubahan status pekerjaan, tekanan kelompok, sosial budaya.

\subsubsection{Tingkat Kecemasan}

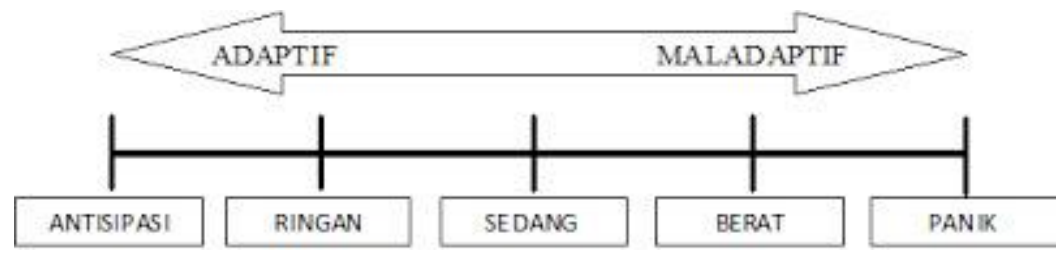


1. Kecemasan ringan

Kecemasan ringan berhubungan dengan ketegangan akan peristiwa kehidupan sehari-hari. Pada tingkat ini lapangan persepsi melebar dan individu akan berhati-hati dan waspada. Individu terdorong untuk belajar yang akan menghasilkan pertumbuhan dan kreatifitas.

a. Respon Fisiologi:

1) Sesekali napas pendek

2) Nadi dan tekanan darah naik

3) Gejala ringan pada lambung

4) Muka berkerut dan bibir bergetar

b. Respon Kognitif

1) Lapang persepsi melebar

2) Mampu menerima rangsangan yang kompleks

3) Konsentrasi pada masalah

4) Menjelaskan masalah secara efektif

c. Respon Perilaku dan Emosi:

1) Tidak dapat duduk tenang

2) Tremor halus pada tangan

3) Suara kadang-kadang meninggi

2. Kecemasan Sedang

Pada tingkat ini lapangan persepsi terhadap lingkungan menurun. Individu lebih memfokuskan hal-hal penting saat itu dan menyampingkan hal lain.

a. Respon Fisiologi:

1) Nadi (ekstra systole) dan tekanan darah naik

2) Mulut kering

3) Anorexia

4) Diare/konstipasi

5) Gelisah 
b. Respon Kognitif:

1) Lapang persepsi menyempit

2) Rangsang luar tidak mampu diterima

3) Berfokus pada apa yang menjadi perhatian

c. Respon Perilaku dan Emosi:

1) Gerakan tersentak-sentak (meremas tangan)

2) Bicara banyak dan lebih cepat

3) Susah tidur

4) Perasaan tidak aman

3. Kecemasan Berat

Pada kecemasan berat lapangan persepsi menjadi sangat sempit, individu cenderung memikirkan hal yang kecil saja dan mengabaikan hal lain. Individu tidak mampu lagi berpikir realistis dan membutuhkan banyak pengarahan untuk memusatkan perhatian pada area lain.

a. Respon Fisiologi:

1) Sering napas pendek

2) Nadi (ekstra systole) dan tekanan darah naik

3) Berkeringat dan sakit kepala

4) Penglihatan kabur

5) Ketegangan

b. Respon Kognitif:

1) Lapang persepsi sangat sempit

2) Tidak mampu menyelesaikan masalah

c. Respon Perilaku dan Emosi:

1) Perasaan ancaman meningkat

2) Verbalisasi cepat

3) Blocking

4. Panik

Pada tingkatan ini lapangan persepsi individu sudah sangat menyempit dan sudah terganggu sehingga tidak dapat 
mengendalikan diri lagi dan tidak dapat melakukan apa-apa walaupun telah di berikan pengarahan.

a. Respon Fisiologi

1) Sistem Kardiovaskuler
a) Palpitasi
b) Jantung berdebar
c) Tekanan darah meningkat
d) Denyut nadi menurun
e) Rasa mau pingsan

2) Sistem Respirasi
a) Napas cepat
b) Pernapasan dangkal
c) Rasa tertekan pada dada
d) Pembengkakan pada tenggorokan
e) Rasa tercekik
f) Terengah-engah

3) Sistem Gastrointestinal
a) Kehilangan nafsu makan
b) Menolak makanan
c) Perasaan dangkal
d) Rasa tidak nyaman pada abdominal
e) Rasa terbakar pada jantung
f) Diare

4) Sistem Perkemihan
a) Inkontensia urine
b) Sering miksi

5) Sistem integument
a) Rasa terbakar
b) Berkeringat banyak di telapak tangan Gatal-gatal
c) Perasaan panas atau dingin pada kulit
d) Muka pucat
e) Berkeringat seluruh tubuh 
b. Respon Kognitif

1) Gangguan perhatian

2) Konsentrasi hilang

3) Pelupa

4) Salah tafsir

5) Adanya bloking pada fikiran

6) Bingung

7) Rasa khawatir yang berlebihan

8) Kehilangan penilaian objektifitas

9) Takut akan kehilangan kembali

10) Takut berlebihan

c. Respon Perilaku dan Emosi

1) Agitasi, mengamuk dan marah

2) Ketakutan, berteriak-teriak, blocking

3) Kehilangan kendali atau kontrol diri

4) Persepsi Kacau

d. Perilaku

1) Gelisah

2) Ketegangan fisik

3) Tremor

4) Gugup bicara cepat

5) Tidak ada koordinasi

6) Kecenderungan untuk celaka

7) Menarik diri

8) Menghindar

9) Terhambat melakukan aktifitas

\subsubsection{Mekanisme Koping}

Ketika pasien mengalami ansietas, individu menggunakan bermacam macam mekanisme koping untuk mencoba mengatasinya. Dalam bentuk ringan ansietas bentuk ringan ansietas dapat di atasi dengan menangis, tertawa, tidur, olahraga atau merokok. Bila terjadi ansietas berat sampai 
panik akan terjadi ketidak mampuan mengatasi ansietas secara konstruktif merupakan penyebab utama perilaku yang patologis, individu akan menggunakan energy yang lebih besar untuk dapat mengatasi ancaman tersebut.

Mekanisme koping untuk mengatasi ansietas adalah:

1. Reaksi yang berorientasi pada tugas (task oriented reaction) Merupakan pemecahan masalah secara sadar yang digunakan untuk menanggulangi ancaman stressor yang ada secara realistis yaitu:

a. Perilaku menyerang (Agresif) Biasanya digunakan individu untuk mengatasi rintangan agar memenuhi kebutuhan.

b. Perilaku menarik diri Digunakan untuk menghilangkan sumber ancaman baik secara fisik maupun psikologis.

c. Perilaku kompromi Digunakan untuk merubah tujuan yang akan dilakukan atau mengorbankan kebutuhan personal untuk mencapai tujuan.

2. Mekanisme pertahanan ego (Ego oriented reaction) Mekanisme ini membantu mengatasi ansietas ringan dan sedang yang digunakan untuk melindungi diri dan dilakukan secara sadar untuk mempertahankan keseimbangan. Mekanisme pertahanan ego:

a. Disosiasi adalah pemisahan dari proses mental atau perilaku dari kesadaran atau identitasnya.

b. Identifikasi (identification) adalah proses dimana seseorang untuk menjadi yang ia kagumi berupaya dengan mengambil/meniru pikiranpikiran, perilaku dan selera orang tersebut.

c. Intelektualisasi (intellectualization) adalah penggunaan logika dan alasan yang berlebihan untuk menghindari pengalaman yang mengganggu perasaannya.

d. Introjeksin (introjection) adalah suatu jenis identifikasi yang dimana seseorang mengambil dan melebur nilai-nilai dan kualitas seseorang atau suatu kelompok kedalam struktur egonya sendiri, berupa hati nurani, contohnya rasa benci atau kecewa 
terhadap kematian orang yang dicintai, dialihkan dengan cara menyalahkan diri sendiri.

e. Kompensasi adalah proses dimana seseorang memperbaiki penurunan citra diri dengan secara tegas menonjolkan keistimewaan/kelebihan yang dimilikinya. Penyangkalan (Denial) adalah menyatakan ketidaksetujuan terhadap realitas dengan mengingkari realitas tersebut. Mekanisme pertahanan ini adalah penting, sederhana, primitif.

f. Pemindahan (displacement) adalah pengalihan emosi yang semula ditujukan pada seseorang/benda kepada orang lain/benda lain yang biasanya netral atau kurang mengancam dirinya.

g. Isolasi adalah pemisahan unsur emosional dari suatu pikiran yang menggangu dapat bersifat sementara atau berjangka lama.

h. Proyeksi adalah pengalihan buah pikiran atau impuls pada diri sendiri kepada orang lain terutama keinginan, perasaan emosional dan motivasi yang tidak dapat ditoleransi.

i. Rasionalisasi adalah mengemukakan penjelasan yang tampak logis dan dapat diterima masyarakat untuk membenarkan perasaan perilaku dan motif yang tidak dapat diterima.

j. Reaksi formasi adalah pengembangan sikap dan pola perilaku yang ia sadari yang bertentangan dengan apa yang sebenarnya ia rasakan atau ingin dilakukan.

k. Regresi adalah kemunduran akibat stress terhadap perilaku dan merupakan ciri khas dari suatu taraf perkembangan yang lebih dini.

1. Represi adalah pengenyampingkan secara tidak sadar tentangtentang pikiran, ingatan yang menyakitkan atau bertentangan ,dari kesadaran seseorang merupakan pertahanan ego yang primer yang cenderung diperkuat oleh mekanisme lain. 


\subsubsection{Penatalaksanaan}

Menurut Hawari (Yogiantoro, 2017) penatalaksanaan ansietas pada tahap pencegahaan dan terapi memerlukan suatu metode pendekatan yang bersifat holistik, yaitu mencangkup fisik (somatik), psikologik atau psikiatrik, psikososial dan psikoreligius. Selengkpanya seperti pada uraian berikut :

1. Upaya meningkatkan kekebalan terhadap stress, dengan cara :
a. Makan makanan yang berigizi dan seimbang
b. Tidur yang cukup
c. Olahraga yang teratur
d. Tidak merokok dan tidak minum minuman keras

2. Terapi Psikofarmaka

Terapi psikofarmaka yang sering dipakai adalah obat anti cemas (anxiolytic), yaitu seperti diazepam, clobazam, bromazepam, lorazepam, buspirone $\mathrm{HCl}$, meprobamate dan alprazolam.

4. Terapi Somatik

Gejala atau keluhan fisik (somatik) sering dijumpai sebagai gejala ikutan atau akibat dari kecemasan yang bekerpanjangan. Untuk menghilangkan keluhan-keluhan somatik (fisik) itu dapat diberikan obat-obatan yang ditujukan pada organ tubuh yang bersangkutan.

5. Psikoterapi

Psikoterapi diberikan tergantung dari kebutuhan individu, antara lain

b. Psikoterapi Suportif

c. Psikoterapi Re-Edukatif

d. Psikoterapi Re-Konstruktif

e. Psikoterapi Kognitif

f. Psikoterapi Psikodinamik

g. Psikoterapi Keluarga

6. Terapi Psikoreligius

Untuk meningkatkan keimanan seseorang yang erat hubungannya dengan kekebalan dan daya tahan dalam menghadapi berbagai problem kehidupan yang merupakan stressor psikososial. 


\section{BAB 3}

\section{TINJAUAN KASUS}

\subsection{Pengkajian Keperawatan}

\begin{tabular}{|c|c|}
\hline $\begin{array}{l}\text { Nama : Ny. S } \\
\text { Usia : } 65 \text { tahun } \\
\text { Tahun no reg :- } \\
\text { Ruangan :- } \\
\text { Tgl masuk rs: - } \\
\text { Tgl pengkajian : } 1 \text { Oktober } \\
2021 \text { : Jalan Bakti Luhur } \\
\text { Alamat : } \\
\text { Medan Helvetia }\end{array}$ & $\begin{array}{l}\text { Kondisi saat MRS: Keluarga pasien mengatakan lemas dan gelisah, } \\
\text { pasien memiliki riwayat hipertensi. } \\
\text { Kondisi saat ini : } \\
\text { Ny. S mengeluh badannya terasa lemas, kehilangan selera makan, tekanan darah } \\
\text { tinggi sehingga Ny. S tidak mampu melakukan aktivitas seperti biasanya, hingga } \\
\text { membuat Ny. S merasa takut, gelisah dan tidak dapat melakukan aktifitas seperti } \\
\text { biasa. }\end{array}$ \\
\hline
\end{tabular}

1. Faktor Predisposisi Dan Faktor Presipitasi

\begin{tabular}{|c|c|c|c|c|}
\hline \multirow{2}{*}{ Faktor predisposisi } & \multicolumn{3}{|l|}{ Faktor presipitasi } & \multirow[t]{2}{*}{ STRESSOR } \\
\hline & Nature & Origin & $\begin{array}{l}\text { Number } \quad \& \\
\text { Timing }\end{array}$ & \\
\hline $\begin{array}{l}\text { Biologis: } \\
\text { 1. Hipertensi } \\
\text { 2. Ny. S menderita gagal ginjal kronis tahun yang } \\
\text { lalu } \\
\text { 3. Ny. S sering mengkonsumsi makanan tinggi } \\
\text { garam } \\
\text { 4. Ny. S tidak rutin check up kepelayanan } \\
\text { kesehatan }\end{array}$ & $\begin{array}{lr}\text { Badannya } & \text { terasa } \\
\text { lemas, } & \text { kehilangan } \\
\text { selera } & \text { makan, } \\
\text { tekanan } & \text { darah } \\
\text { tinggi } & \\
\end{array}$ & Internal & $\begin{array}{lr}\text { Sejak } & 2 \\
\text { minggu } & \text { yang } \\
\text { lalu } & \end{array}$ & - Hipertensi \\
\hline
\end{tabular}




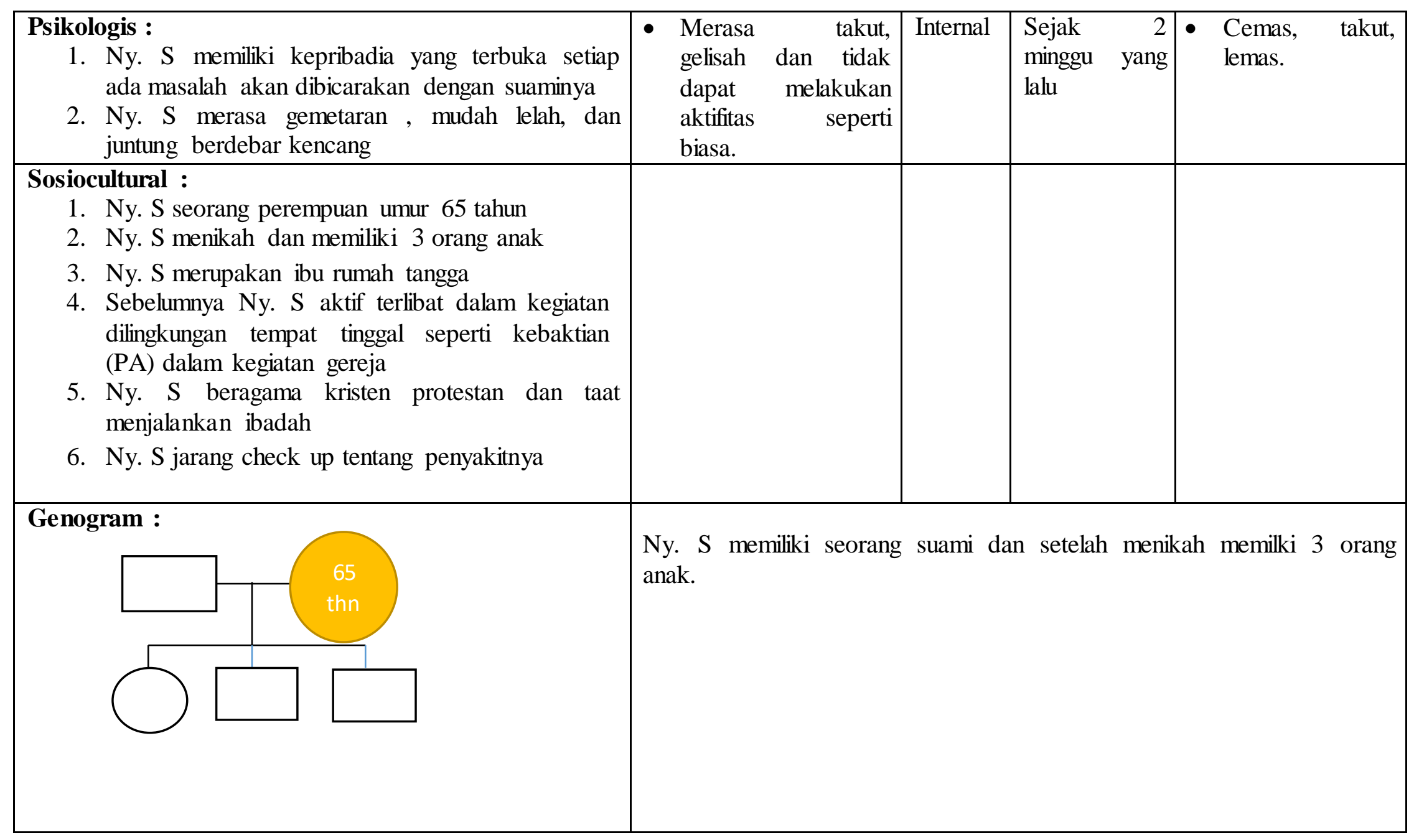




\begin{tabular}{|c|c|c|c|c|c|c|}
\hline STRESSOR & KOGNITIF & AFEKTIF & FISIOLOGIS & PERILAKU & SOSIAL & $\begin{array}{l}\text { DIAGNOSA } \\
\text { KEPERAWATAN }\end{array}$ \\
\hline \begin{tabular}{|l} 
BIOLOGIS \\
- Hipertensi
\end{tabular} & 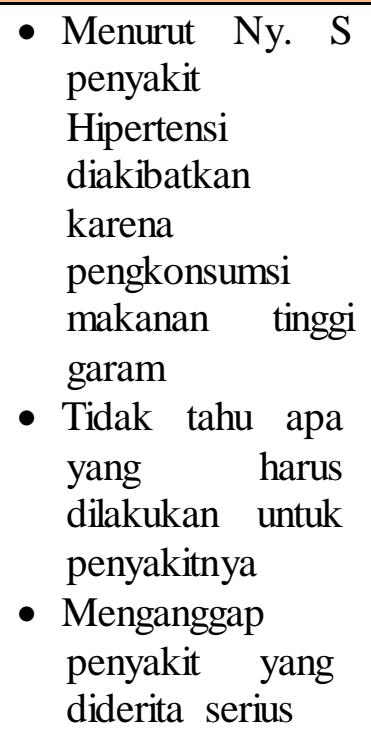 & $\begin{array}{l}\text { Ny. } \\
\text { merasa } \\
\text { dan sedih } \\
\text { bingung } \\
\text { dengan } \\
\text { kondisi } \\
\text { penyakitnya } \\
\text { saat ini }\end{array}$ & $\begin{array}{l}\text { - } \text { Cemas } \\
\text { - Sulit tidur } \\
\text { - Tidak nafsu } \\
\text { makan } \\
\text { - Ny. S tampak } \\
\text { lemas } \\
\text { - Pemeriksaan } \\
\text { TTV } \\
\text { TD: } 170 / 90 \\
\mathrm{mmHg} \\
\mathrm{N}: 88 \mathrm{x} / \text { menit } \\
\mathrm{P}: 20 \mathrm{x} / \text { menit } \\
\text { S: } 37{ }^{0} \mathrm{C}\end{array}$ & 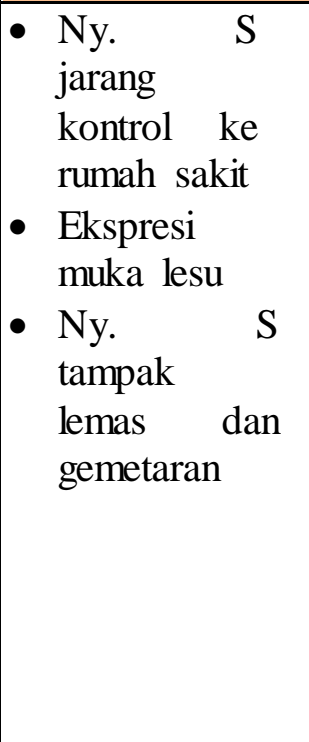 & \begin{tabular}{|l} 
- \\
Pasien \\
mendatangi \\
dan \\
menggunakan \\
fasilitas \\
kesehatan yang \\
ada untuk \\
mencari \\
kesembuhan \\
terhadap \\
masalah yang \\
dihadapi saat \\
ini
\end{tabular} & - Ansietas \\
\hline \begin{tabular}{|l} 
PSIKOLOGIS \\
- Sedih, cemas, \\
lemas dan \\
Kehilangan \\
selera makan \\
dengan kondisi
\end{tabular} & $\begin{array}{l}\text { - Ny. S tahu } \\
\text { bahwa } \\
\text { badannya terasa } \\
\text { lemas, } \\
\text { kehilangan } \\
\text { selera makan, } \\
\text { tekanan darah }\end{array}$ & $\begin{array}{ll}\text { - } & \text { Merasa } \\
\text { dengan } & \\
\text { penyakitnya } \\
\text { yang tidak } \\
\text { yen } \\
\text { sembuh- } \\
\text { sembuh }\end{array}$ & $\begin{array}{l}\text { - Sakit kepala } \\
\text { - Sulit tidur dan } \\
\text { sering } \\
\text { terbangun } \\
\text { apabila tidur } \\
\text { - Tidak nafsu } \\
\text { makan }\end{array}$ & $\begin{array}{l}\text { - Tampak } \\
\text { cemas dan } \\
\text { tidak } \\
\text { tenang } \\
\text { - Kadang } \mathrm{Ny} . \\
\mathrm{S} \mathrm{tampak} \\
\text { murung }\end{array}$ & $\begin{array}{l}\text { - Hubungan Ny. } \\
\text { S dengan } \\
\text { keluarga baik } \\
\text { - Sikap Ny. S } \\
\text { pasif dalam } \\
\text { menerima } \\
\text { perawatan }\end{array}$ & - Ansietas \\
\hline
\end{tabular}




\begin{tabular}{|c|c|c|c|c|c|}
\hline $\begin{array}{l}\text { penyakit dan } \\
\text { pengobata } \\
\text { n serta } \\
\text { Perawatannya }\end{array}$ & 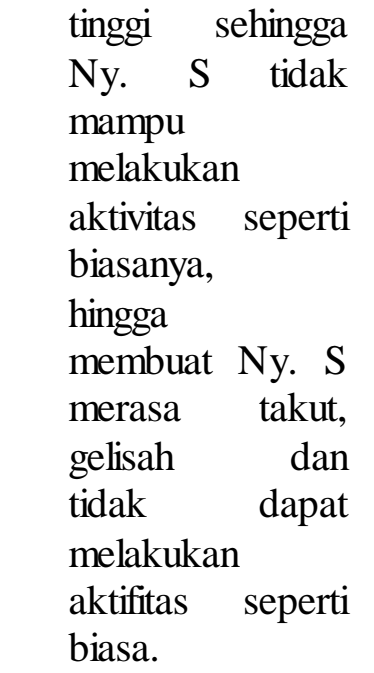 & & $\begin{array}{l}\text { - Ny. S tampak } \\
\text { lemas } \\
\text { - Wajah Ny. S } \\
\text { tampak lemas } \\
\text { - Pemeriksaan } \\
\text { TTV } \\
\text { TD: } 170 / 90 \\
\text { mmhg } \\
\text { N : } 88 \times \text { x menit } \\
\text { P : } 20 \times / \text { menit } \\
\text { S: } 37{ }^{0} \mathrm{C}\end{array}$ & 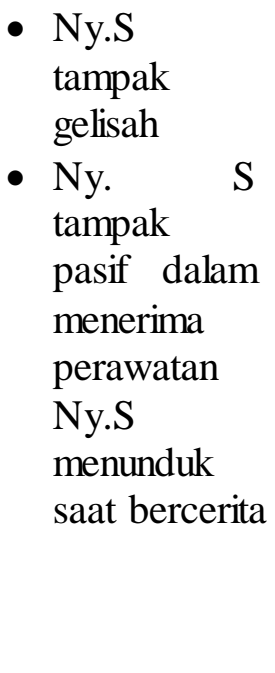 & \\
\hline $\begin{array}{l}\text { SOSIAL } \\
\text { BUDAYA } \\
\text { - Ny. S merasa } \\
\text { memikirkan } \\
\text { keluarga yang } \\
\text { masih yang harus } \\
\text { menjaga dan } \\
\text { merawatnya setiap } \\
\text { hari. }\end{array}$ & $\begin{array}{l}\text { - Ny. S merasa } \\
\text { harga dirinya } \\
\text { rendah } \\
\text { keadaannya } \\
\text { dengan keadaan } \\
\text { yang tidak bisa } \\
\text { bekerja bingung } \\
\text { memikirkan } \\
\text { anak-anak, } \\
\text { menurut pasien, } \\
\text { dukungan } \\
\text { keluarga nomor } \\
\text { satu }\end{array}$ & $\begin{array}{l}\text { - Merasa } \\
\text { khawatir dan } \\
\text { sedih kepada } \\
\text { suami yang } \\
\text { merawatnya } \\
\text { setiap hari } \\
\text { - Merasa } \\
\text { bersalah } \\
\text { karena } \\
\text { merasa } \\
\text { merepotkan } \\
\text { suami } \\
\text { Merasa }\end{array}$ & $\begin{array}{l}\text { - Pusing } \\
\text { - Mual } \\
\text { - Mulut tampak } \\
\text { kering } \\
\text { - Sulit tidur } \\
\text { - Tidak nafsu } \\
\text { makan } \\
\text { - Ny. S tampak } \\
\text { lemas } \\
\text { - Wajah Ny. S } \\
\text { tampak pucat } \\
\text { Pemeriksaan }\end{array}$ & $\begin{array}{l}\text { - Ny. } \\
\text { tampak } \\
\text { gelisah }\end{array}$ & $\begin{array}{l}\text { - Hubungan } \\
\text { Ny. S dengan } \\
\text { keluarga baik } \\
\text { - Hubungan } \\
\text { Ny. S dengan } \\
\text { petugas } \\
\text { kesehatan } \\
\text { baik } \\
\text { - Ny. S tetap } \\
\text { mengikuti } \\
\text { program } \\
\text { pengobatan }\end{array}$ \\
\hline
\end{tabular}

Ketidakberdayaan

Harga Diri Rendah 


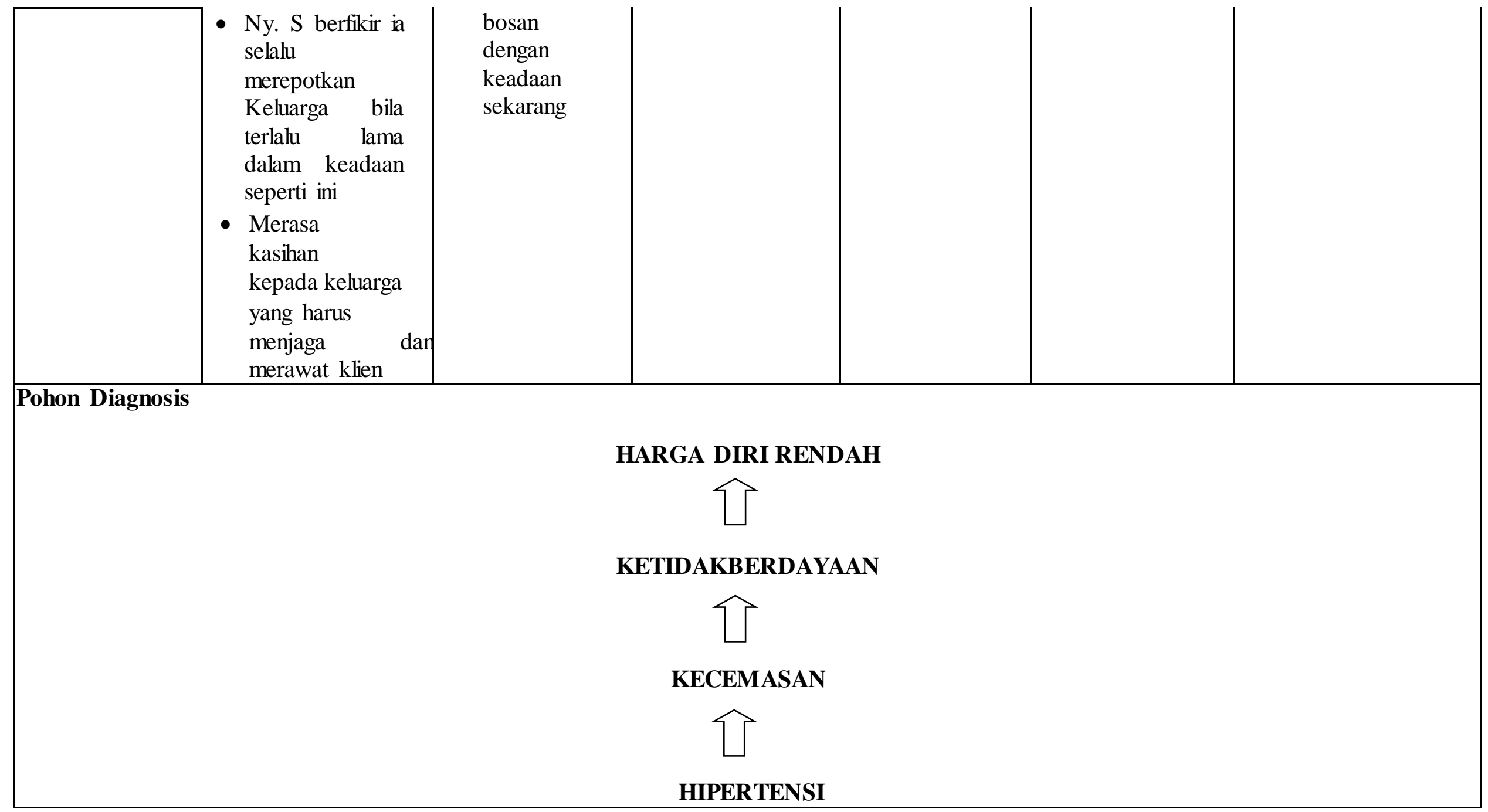


2. SUMBER KOPING

\begin{tabular}{|c|c|c|c|c|c|}
\hline $\begin{array}{c}\text { DIAGNOSA } \\
\text { KEPERAWATAN }\end{array}$ & PERSONAL ABILITY & $\begin{array}{c}\text { SOSIAL } \\
\text { SUPPORT }\end{array}$ & $\begin{array}{c}\text { MATERIAL } \\
\text { ASSETS }\end{array}$ & $\begin{array}{l}\text { POSITIE } \\
\text { BELIEFS }\end{array}$ & TERAPI \\
\hline Ansietas & $\begin{array}{l}\text { - Ny. S mampu } \\
\text { mengungkapkan } \\
\text { perasaan cemas } \\
\text { - Ny. S mengatakan bila } \\
\text { cemasnya memuncak } \\
\text { maka ia akan berdoa }\end{array}$ & $\begin{array}{l}\text { - Ny. S mendapat } \\
\text { dukungan dari } \\
\text { keluarga untuk } \\
\text { kesembuhannya } \\
\text { dan keluarga } \mathrm{Ny} \text {. } \\
\mathrm{S} \text { bergantian } \\
\text { merawat pasien }\end{array}$ & $\begin{array}{l}\text { - Sosial ekonomi } \\
\text { Ny. S menengah } \\
\text { dan pengobatan } \\
\text { ditanggung biaya } \\
\text { pribadi } \\
\text { - Jarak rumah } \mathrm{Ny} \text {. } \\
\mathrm{S} \text { dengan tempat } \\
\text { pelayanan } \\
\text { kesehatan lebih } \\
\text { kurang } 2 \mathrm{~km}\end{array}$ & $\begin{array}{l}\text { - Ny. S percaya bahwa } \\
\text { petugas kesehatan } \\
\text { akan membantunya } \\
\text { - Ny. S berharap cepat } \\
\text { sembuh agar tidak } \\
\text { merepotkan } \\
\text { Keluarga }\end{array}$ & 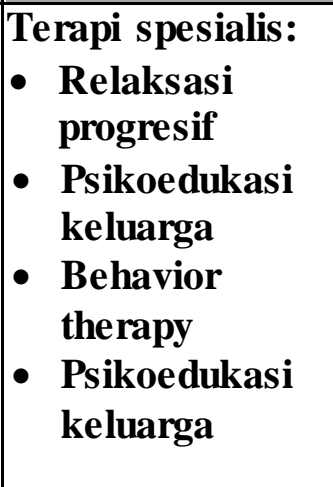 \\
\hline Kurang pengetahuan & $\begin{array}{l}\text { - Ny. S mampu } \\
\text { mengenal dan menilai } \\
\text { penyakitnya } \\
\text { - Ny. S mampu melatih } \\
\text { cara hidup sehat }\end{array}$ & $\begin{array}{l}\text { Ny. S mendapat } \\
\text { dukungan dari } \\
\text { keluarga untuk } \\
\text { kesembuhannya } \\
\text { terutama dari } \\
\text { keluarga nya } \\
\text { - Keluarga Ny. S } \\
\text { bergantian } \\
\text { menjaga dan } \\
\text { mengunjungi } \\
\text { pasien }\end{array}$ & $\begin{array}{l}\text { - Sosial ekonomi } \\
\text { Ny. S menengah } \\
\text { - Ny. S tinggal di } \\
\text { rumah sendiri } \\
\text { - Sarana dan } \\
\text { prasarana } \\
\text { tersedia } \\
\text { - Biaya } \\
\text { pengobatan } \\
\text { ditanggung } \\
\text { keluarga } \\
\text { sendiri } \\
\text { - Jarak rumah Ny S }\end{array}$ & $\begin{array}{l}\text { - Ny. S percaya bahwa } \\
\text { petugas kesehatan } \\
\text { akan membantunya } \\
\text { - Ny. S berharap } \\
\text { cepat sembuh agar } \\
\text { tidak merepotkan } \\
\text { keluarganya } \\
\text { - Ny. S selalu } \\
\text { berdoa untuk } \\
\text { kesembuhan } \\
\text { penyakitnya } \\
\text { Ny. S yakin, bila ia } \\
\text { mengikuti }\end{array}$ & 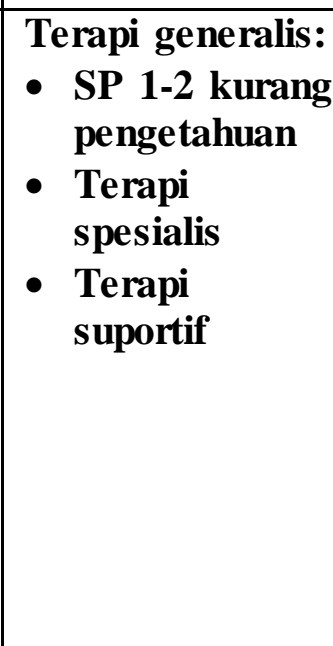 \\
\hline
\end{tabular}




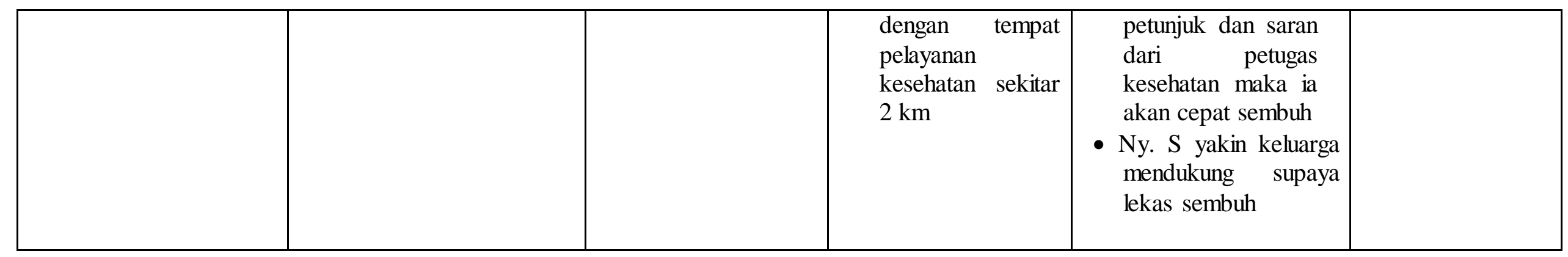




\section{MEKANISME KOPING}

\begin{tabular}{|c|c|}
\hline $\begin{array}{l}\text { HAL YANG } \\
\text { DILAKUKAN }\end{array}$ & ANALISA \\
\hline $\begin{array}{l}\text { - Ny. S mengatakan bila ada masalah, maka ia akan membicarakan } \\
\text { dengan suami dan keluarga untuk mencari jalan keluarnya } \\
\text { - Bila sakit Ny. S berobat ke pelayanan kesehatan } \\
\text { - Ny. S taat menjalankan ibadah sesuai dengan keyakinan yang ia miliki } \\
\text { - Ny. S selalu berdoa kepada Tuhan untuk kesembuhannya }\end{array}$ & $\begin{array}{l}\text { - Konstruktif: } \\
\checkmark \text { Ny. S mengatakan bila ada masalah, maka ia akan } \\
\text { membicarakan dengan keluarga untuk mencari jalan } \\
\text { keluarnya } \\
\checkmark \text { Bila sakit Ny. S berobat ke pelayanan kesehatan } \\
\checkmark \text { Ny. S taat menjalankan ibadah sesuai } \\
\text { dengan keyakinannya } \\
\checkmark \text { Ny. S selalu berdoa kepada Tuhan untuk } \\
\text { kesembuhannya. } \\
\text { - Destruktif : - }\end{array}$ \\
\hline
\end{tabular}




\section{STATUS MENTAL}

\begin{tabular}{|l|l|}
\hline 1. Penampilan & Bersih, dan rapi \\
\hline 2. Pembicaraan & Ramah dan mau menceritakan semua hal yang dialami saat ini \\
\hline 3. Aktivitas motoric & Mampu berinteraksi \\
\hline 4. Interaksi selama wawancara & Ada kontak mata saat wawancara namun tidak tetap \\
\hline 5. Alam perasaan & Sedih, merasa cemas ,takut dan bingung mengenai penyakit yang dialami \\
\hline 6. Afek & Datar \\
\hline 7. Persepsi & Tidak ada gangguan persepsi dan sensori \\
\hline 8. Isi piker & Tidak ada gangguan isi piker \\
\hline 9. Proses piker & Tidak ada ganggu proses piker \\
\hline 10. Tingkat kesadaran & Normal \\
\hline 11. Daya ingat & Normal \\
\hline 12. Kemampuan berhitung & Tidak ada gangguan dalam berhitung \\
\hline 13. Penilaian & Ny. S mengambil keputusan saat merasa sakit dengan beribadah dan berdoa \\
\hline 14. Daya tilik diri & Ny. S menyadari memang merasa cemas \\
& \\
\hline
\end{tabular}


5. DIAGNOSA DAN TERAPI

\begin{tabular}{|l|l|}
\hline DIAGNOSA KEPERAWATAN DAN TERAPI & DIAGNOSA MEDIS DAN TERAPI MEDIS \\
KEPERAWATAN & Hipertensi \\
\hline 1. Ansietas & \\
- Sp1: Mendiskusikan penyebab, terjadinya proses terjadi, & \\
- Sp2 :Melatih teknik releksasi fisik & \\
- Sp3:Melati mengatasi ansietas dengan distraksi dan & \\
- Sipnotis lima jari & \\
2. Ketidakberdayaan & \\
- Sp1. Assement ketidakerdayaan dan latihan berpikir positif & \\
- Sp2. Manfaat mengembangkan harapan positif dan latihan & \\
mengontrol perasaan & \\
3. Koping in efektif & \\
Terapi perilaku & \\
\end{tabular}




\section{IMPLEMENTASI TINDAKAN KPERAWATAN DAN EVALUASI}

\begin{tabular}{|c|c|}
\hline IMPLEMENTASI TINDAKAN KPERAWATAN & EVALUASI \\
\hline $\begin{array}{l}\text { Tanggal : } 01 \text { Oktober } 2021 \\
\text { Jam : } 09.00 \text { wib } \\
\text { a. Kaji tanda dan gejala ansietas dan kemampuan klien mengurangi } \\
\text { kecemasan } \\
\text { b. Jelaskan tanda dan gejala, penyebab dan akibat dari kecemasan } \\
\text { c. Latihan cara mengatasi kecemasan : } \\
\text { 1) Teknik relaksasi napas dalam } \\
\text { 2) Distraksi : bercakap-cakap hal positif } \\
\text { 3) Hipnotis } 5 \text { jari fokus padahal-hal yang positif } \\
\text { d. Bantu klien melakukan latihan sesuai dengan jadwal kegiatan. }\end{array}$ & \begin{tabular}{|ll} 
S : & - \\
& Klien mengatakan : merasa lebih tenang tetapi belum \\
& sepenuhnya cemasnya hilang \\
& - \\
& Klien mengatakan ia mampu mengindentifikasi situasi \\
& yang mencetus ansietas \\
O : & Klien tampak rileks dan tidak gelisah lagi \\
& - \\
& Klen mampu menjelaskan kembali penjelasan yang \\
A : & Ansietas (+) \\
P : & Evaluasi SP-1 dan SP-2 \\
- & Latihan cara mengatasi kecemasan : \\
& - Teknik relaksasi napas dalam \\
& - Distraksi : bercakap-cakap hal positif \\
& - Hipnotis 5 jari fokus padahal-hal yang positif \\
Bantu klien melakukan latihan sesuai dengan jadwal kegiatan
\end{tabular} \\
\hline
\end{tabular}




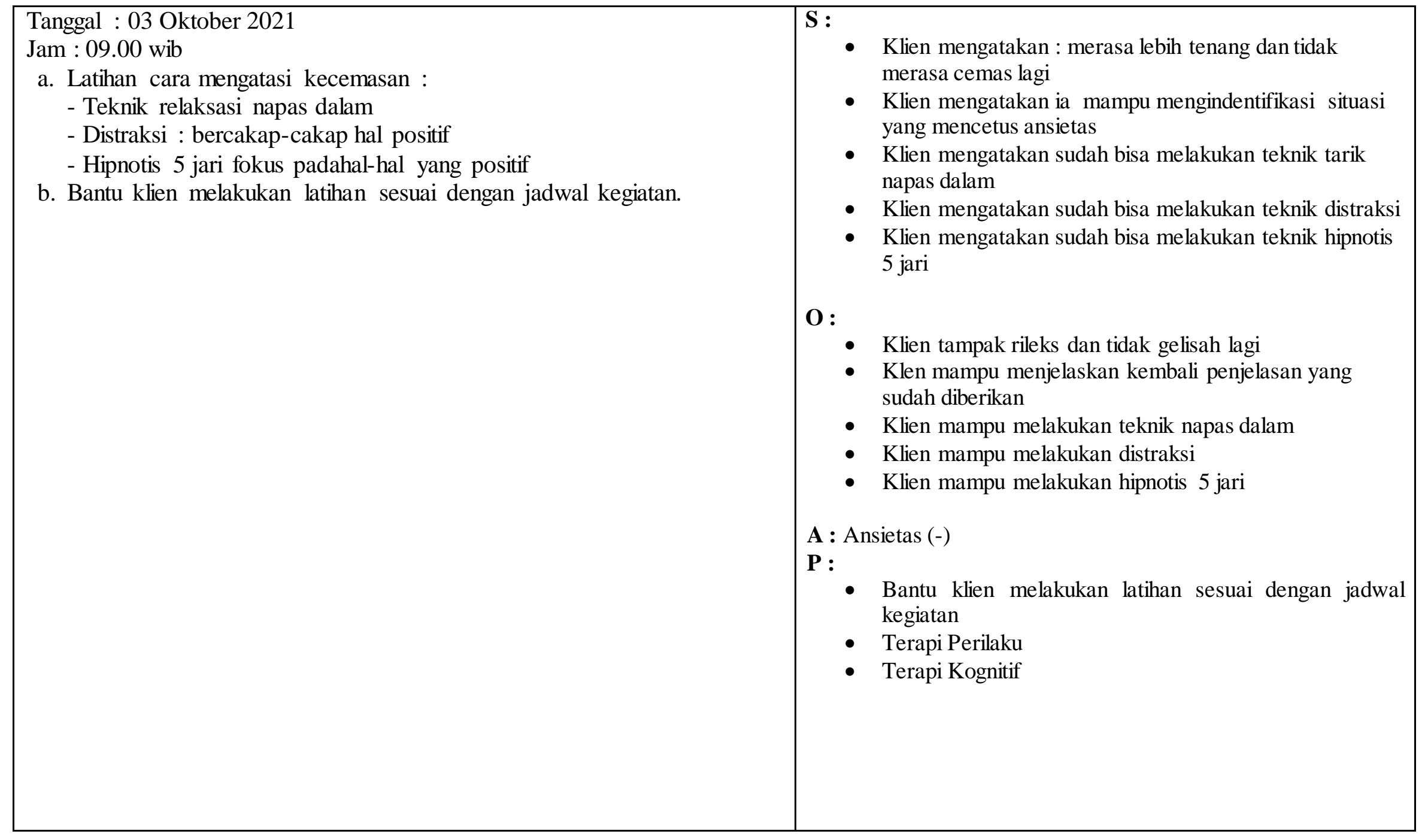




\begin{tabular}{|c|c|}
\hline $\begin{array}{l}\text { Tanggal: } 04 \text { Oktober } 2021 \\
\text { Jam: } 10.00 \text { wib } \\
\text { 1. Melakukan salam teraupetik } \\
\text { 2. Menanyakan kepada klien faktor penyebab penyakit } \\
\text { 3. Menanyakan kepada klien mengapa merasa cemas dan tidak berdaya } \\
\text { 4. Mengajarkan cara relaksasi untuk mengurangi kecemasan } \\
\text { 5. Mengajarkan klien latihan berpikir positif } \\
\text { 6. mendiskusikan ketidakberdayaan yang dialami pasien }\end{array}$ & $\begin{array}{l}\text { Pendidikan Kesehatan } \\
\text { S: - Klien mengatakan kecemasan berkurang } \\
\text {. Klien mengatakan perasaan tidak berdaya semakin } \\
\text { berkurang dan akan berpikir positif } \\
\text { O: - Klien tampak tenang saat mengungkapkan } \\
\text { perasaanyan dan selalau melakukan terapi tarik napas } \\
\text { dalam } \\
\quad \text { - Klien menceritakan ketidak berdayaannya, } \\
\quad \text { penyebab dll. } \\
\text { A: Ketidakberdayaan (+) / tujuan tercapai } \\
\text { P Klien: Klien melakukan terapi dirumah } \\
\text { P perawat: Evaluasi terapi satu tercapai. melanjutkan terapi } \\
\text { kedua }\end{array}$ \\
\hline
\end{tabular}




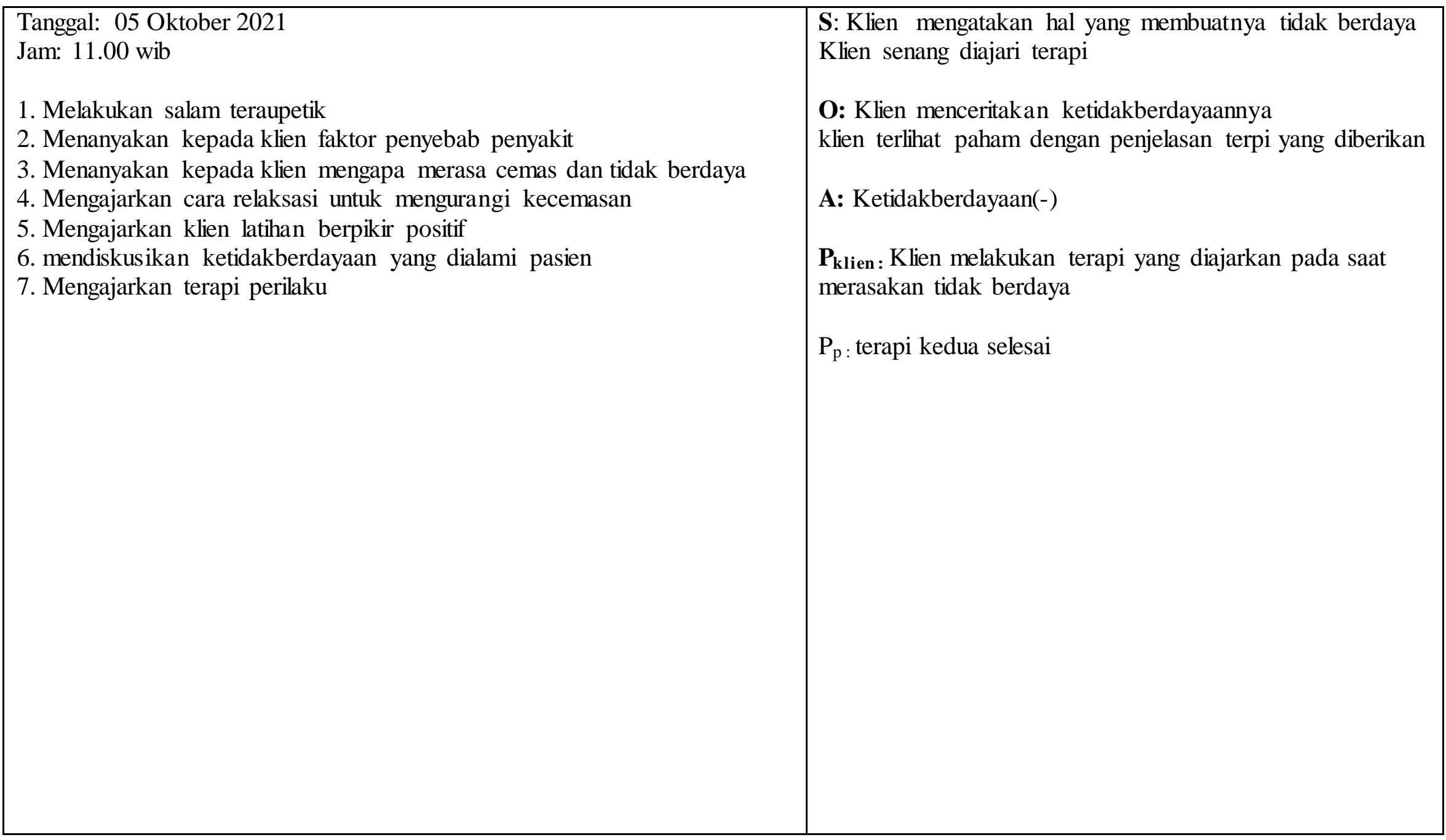




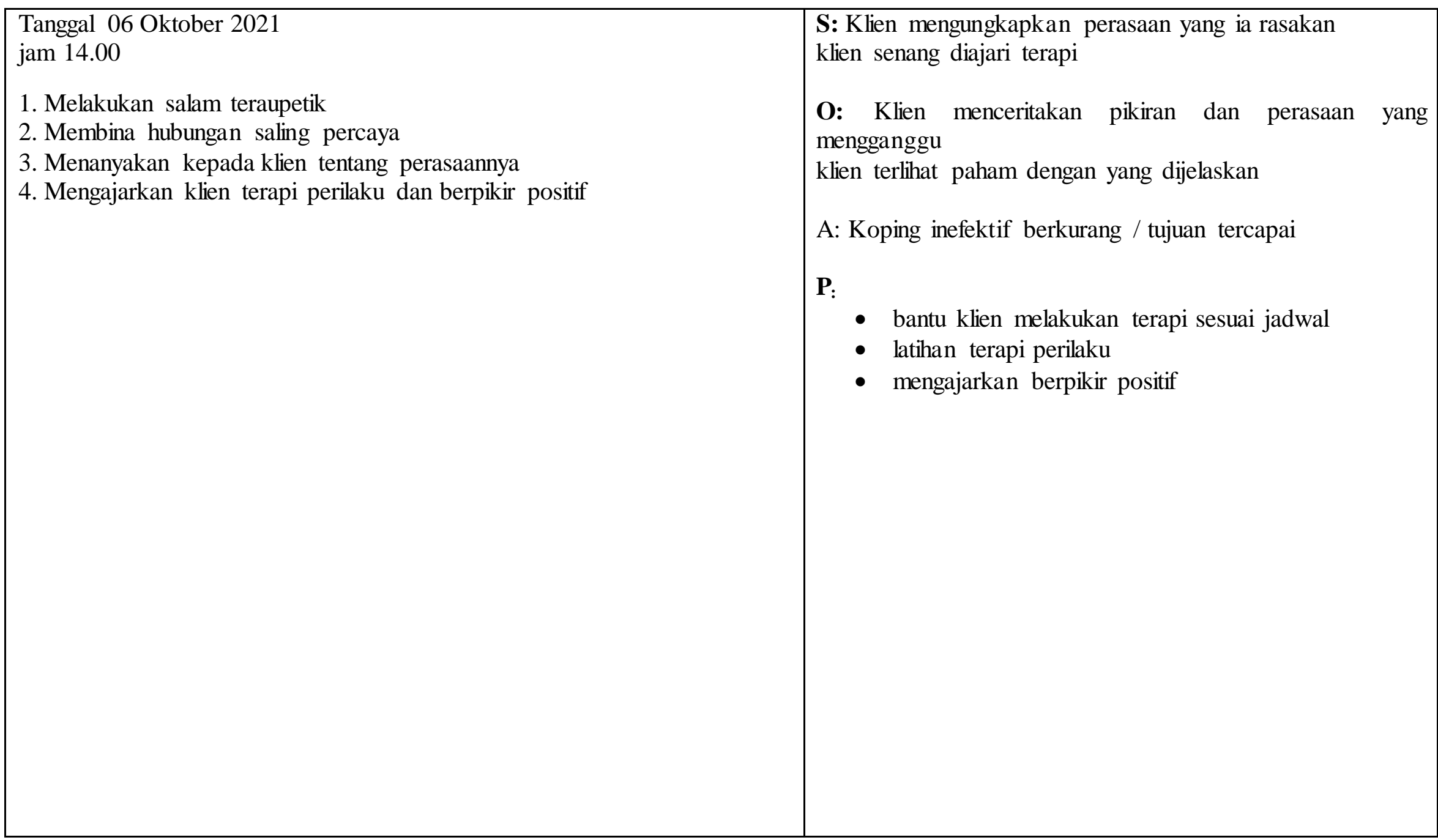




\begin{tabular}{|l|l|}
\hline $\begin{array}{l}\text { Tanggal 07 Oktober 2021 } \\
\text { jam 13.00 }\end{array}$ & $\begin{array}{l}\text { S: Klien mengungkapkan perasaan yang ia rasakan } \\
\text { klien senang diajari terapi } \\
\text { 1. Melakukan salam teraupetik } \\
\begin{array}{l}\text { 2. Membina hubungan saling percaya } \\
\text { 3. Menanyakan kepada klien tentang perasaannya } \\
\text { 4. Mengajarkan klien terapi perilaku dan berpikir positif } \\
\text { mengganggu } \\
\text { klien terlihat paham dengan yang dijelaskan }\end{array} \\
\text { A: Koping inefektif (-) }\end{array}$ \\
$\begin{array}{l}\text { P: } \quad \text { pantu klien melakukan terapi sesuai jadwal } \\
\circ \text { latihan terapi perilaku } \\
\text { mengajarkan berpikir positif }\end{array}$ \\
\hline
\end{tabular}




\section{BAB 4 \\ PEMBAHASAN}

Berdasarkan wawancara yang dilakukan penulis. Penulis mendapatkan hasil yaitu seorang perempuan yang bernama Ny. S. saat dilakukan pengkajian dirumahnya Ny. S mengatakan badanya terasa lemas, kehilangan selera makan, tekanan darah tinggi. Ny. S mengatakan tidak mampu malakukan aktivitas seperti biasanya, sehingga membuat Ny. S merasa takut, Gelisah, dan tidak dapat melakukan aktifitas biasanya, saat melakukan pengukuran tekanan darah didapatkan hasil 170/90 mmHg. Pasien memiliki 3 orang anak dan semua sudah menikah, pasien tinggal di rumah bersama suami dan anak-anaknya. Saat Ny. S merasa lelah Ny. S bercerita dengan

suaminya. Penampilan pasien rapi dan bersih, ramah dan mau menceritakan semua hal yang dialaminya. Saat dilakukan pemberian terapi pasien bias mengikuti instruksi yang diberikan. Evaluasi yang saya lakukan terapi 1 berhasil dan lanjutkan dengan pemberian terapi ke 2.

\subsection{Tahap Pengkajian}

Selama pengkajian dilakukan pengumpulan data dari beberapa sumber, yaitu dari pasien dan tetangga sekitar. Maka penulis melakukan pendekatan kepada pasien melalui komunikasi teraupetik yang lebih terbuka membantu klien untuk memecahkan perasaannya dan juga melakukan observasi kepada pasien. Adapun upaya tersebut yaitu :

a. Melakukan pendekatan dan membina hubungan saling percaya diri pada klien agar klien lebih terbuka dan lebih percaya dengan menggunakan perasaan.

b. Mengadakan pengkajian klien dengan wawancara dalam pengkajian ini, penulis tidak menemukan kesenjangan karena ditemukan hal sama seperti: diteori: Kecemasan adalah keadaan emosi dan pengalaman subyektif individu, tanpa objek yang spesifik karena ketidaktahuan dan mendahului pengalamanya yang baru seperti penyakitnya saat ini 


\subsection{Tahap perencanaan}

Perencanaan dalam proses keperawatan lebih dikenal dengan rencana asuhan keperawatan yang merupakan tahap selanjutnya setelah pangkajian dan penentuan diagnosa keperawatan. Pada tahap perencanaan penulis hanya menyusun rencana tindakan keperawatan sesuai dengan pohon masalah keperawatan yaitu : Kecemasan. Pada tahap ini antara tinjauan teoritis dan tinjaun kasus tidak ada kesenjangan sehingga penulis dapat melaksanakan tindakan seoptimal mungkin dan didukung dengan seringnya bimbingan dengan pembimbing. Secara teoritis digunakan cara strategi pertemuan sesuai dengan diagnosa keperawatan yang muncul saat pengkajian. Adapun upaya yang dilakukan penulis yaitu :

1. Klien mengungkapkan ketidakpastian tentang fluktuasi tingkat energi dan bersikap pasif.

2. Klien menunjukan sikap apatis, depresi terhadap perburukan fisik yang terjadi dengan mengabaikan kepatuhan pasien terhadap program pengobatan

3. Klien mengalami ketergantungan pada orang lain yang dapat mengakibatkan ititabilitas, ketidaksukaan, marah dan rasa bersalah. Klien tidak melakukan praktik perawatan diri ketika ditantang. Klien tidak ikut memantau kemajuan pengobatan. Klien menunjukan ekspresi ketidakpuasan terhadap ketidak mampuan melakukan aktivitas atau tugas sebelumnya. Klien menunjukan ekspresi keraguan tantang performa peran.

\subsection{Tahap Implementasi}

Pada tahap implementasi, penulis hanya mengatasi 1 masalah keperawatan yakni: diagnosa keperawatan Kecemasan merupakan keadaan emosi dan pengalaman subyektif induvidu, tanpa objek spesifik karena ketidaktahuan dan mendahului semua pengalaman yang di alami penyakit Hipertensi 


\subsection{Tahap Evaluasi}

Pada tinjauan teoritis evaluasi yang diharapkan adalah :

a. Membina hubungan saling percaya

b. Mengenali dan mengekspresikan emosinya

c. Mampu mengenal ansietas

d. Mampu mengatasi ansietas melalui teknik releksasi

e. Mampu mengatasi ansietas dengan distraksi

f. Mampu mengatasi ansietas melalui hipnotis lima jari 


\section{BAB 5}

\section{PENUTUP}

\subsection{Kesimpulan}

Berdasarkan uraian pada pembahasan diatas, maka penulis dapat disimpulkan bahwa:

1. Pengkajian dilakukan secara langsung pada klien dan juga dengan menjadikan status klien sebagai sumber informasi yang dapat mendukung data-data pengkajian. Selama proses pengkajian, perawat mengunakan komunikasi terapeutik serta membina hubungan saling percaya antara perawat-klien. Pada kasus Kecemasan : Hipertensi

2. Diagnosa keperawatan yang utama pada klien dengan Kecemasan: Hipertensi

3. Perencanaan dan implementasi keperawatan disesuaikan dengan strategi pertemuan pada pasien.

4. Evaluasi keperawatan yang dilakukan menggunakan metode subyektif, obyektif, assessment dan planing.

\subsection{Saran}

1. Untuk Keluarga

Diharapkan agar individu dan keluarga bisa mengerti tentang penyakit hipertensi, dan meningkatkan perilaku hidup sehat dengan tujuan meningkatkan kualitas hidup.

2. Untuk Masyarakat/Pembaca

Diharapkan kasus dan materi ini dapat dijadikan sebagai bahan ajar dan data untuk menangani dan menghadapi kasus kecemasan pada masalah psikososial. 


\section{DAFTAR PUSTAKA}

1. Triyanto,E. 2014. Pelayanan Keperawatan Bagi Penderita Hipertensi secara terpadu, Graha Ilmu. Jakarta.

2. Hulu, E. K., \& Pardede, J. A. (2016). Dukungan Keluarga Dengan Tingkat Kecemasan Pasien Pre Operatif Di Rumah Sakit Sari Mutiara Medan. Jurnal Keperawatan, 2(1).

3. Marbun, A., Pardede, J. A., \& Perkasa, S. I. (2019). Efektivitas Terapi Hipnotis Lima Jari terhadap Kecemasan Ibu Pre Partum di Klinik Chelsea Husada Tanjung Beringin Kabupaten Serdang Bedagai. Jurnal Keperawatan Priority, 2(2), 92-99. https://doi.org/10.34012/jukep.v2i2.568

4. Setyawan, A., \& Hasnah, K. (2020). Efektivitas Wet Cupping Therapy Terhadap Kecemasan Pada Pasien Hipertensi. Jurnal Kesehatan Kusuma Husada, 212-217. https://doi.org/10.34035/jk.v11 i2.574

5. Kaplan, MN., 2016. Kaplan's Clinical Hypertension. 9th ed. USA : Lippincott Williams \& Wilkins. Lancet ; 358 : 1682-1686.

6. Zahara, F. (2017). Hubungan Antara Kecemasan Dengan Tekanaan Darah Pada Penderita Hipertensi Pada Lansia Di Desa Tambaksari - Banyumas Prosiding Seminar Nasional \& Internasional, 1-6.

7. Kemenkes RI, 2016. Pedoman Teknis Penemuan Dan Tatalaksanaan Hipertensi. Jakarta

8. Pardede, J. A., Sitepu, S. F. A., \& Saragih, M. (2018). The Influence of Deep Breath Relaxation Techniques and Five-Finger Hypnotic Therapy on Preoperative Patient Anxiety. Journal of Psychiatry, 3(1), 1-8.

9. Pardede, J. A. (2020). Standar Asuhan Keperawatan Jiwa Dengan Masalah Kecemasan. Jurnal Ilmu Kesehatan

10. Pardede, J. A., \& Simangunsong, M. M. (2020). Family Support With The Level of Preschool Children Anxiety in the Intravenous Installation. Jurnal Keperawatan Jiwa (JKJ): Persatuan Perawat Nasional Indonesia, 8(3), 234. https://doi.org/10.26714/jkj.8.3.2020.223-234

223-

11. Pardede, J., Simanjuntak, G. V., \& Manalu, N. (2020). Effectiveness of deep breath relaxation and lavender aromatherapy against preoperative patient anxiety. Diversity and Equality in Health and Care, 17(4), 168173. 
12. Kaplan, Saddock, \& Grebb (2010) Sinopsis Psikiatri: Ilmu Pengetahuan Perilaku Psikiatri Klinis. Edisi 2. Dr. I. Made Wiguna S. Jakarta : Bina Rupa Aksara.

13. Lubis \& Afif (2014). Tingkat Kecemasan Orangtua dengan Anak yang akan Dioperasi. Jurnal keperawatan padjajaran. 2(3).

14. Smeltzer, S.C \& Bare B.G. (2010). Buku Ajar Keperawatan Medical Bedah (Edisi 8). Jakarta : EGC

15. Stuart, Keliat \& Pasaribu (2016). Prinsip Dan Praktik Keperawatan Kesehatan Jiwa Stuart. Edisi Indonesia (Buku 1). Singapura:Else vier

16. Pardede, J. A., Hulu, D. E. S. P., \& Sirait, A. (2021). Tingkat Kecemasan Menurun Setelah Diberikan Terapi Hipnotis Lima Jari pada Pasien Preoperatif. Jurnal Keperawatan, 13(1), 265-272.

17. Pardede, J. A., Keliat, B. A., Damanik, R. K., \& Gulo, A. R. B. (2020). Optimalization of Coping Nurses to Overcoming Anxiety in the Pandemic of Covid-19 in Era New Normal. Jurnal Peduli Masyarakat, 2(3), 105-112. https://doi.org/10.37287/jpm.v2i3.128 